\title{
O bem da pessoa, o bem comum e a objecção de consciência
}

The good of the person, the common good and conscientious objection

El bien de la persona, el bien común y la objeción de conciencia

Michel Renaud ${ }^{1}$

\section{Resumo}

Três temas ocupam o espaço desta apresentação. Os primeiros dois debruçam-se na mesma problemática, mas sob um ângulo diferente. A relação entre o bem pessoal e o bem comum pode efectivamente ser objecto de pelo menos dois discursos diferentes, o da ética - e o do direito. Além disso, poderá aparecer estranho ligar a estes dois temas um terceiro, reservado à objecção de consciência. Mas este tem cabimento na medida em que constitui, ao nível da cidadania, uma forma sociopolítica de tensão entre um bem pessoal e um bem comum, de natureza social ou política. Desta maneira, ética, direito e cidadania política interferem quando queremos abrir o processo das relações entre o bem pessoal e o bem comum. O tratamento dos problemas da pandemia não escapou sempre a tais questões espinhosas.

\section{Palavras-chave}

Bem da pessoa. Bem comum. Objecção de consciência.

\begin{abstract}
Three themes occupy the space of this presentation. The first two deal with the same problem, but from a different angle. The relationship between the personal good and the common good can in fact be the subject of at least two different discourses, that of ethics and that of law. In addition, it may seem strange to link these two themes to a third, reserved for conscientious objection. However, this is valid in that it constitutes, at the level of citizenship, a socio-political form of tension between a personal and a common good, of a social or political nature. In this way, ethics, law and political citizenship interfere when we want to open the process of relations between the personal good and the common good. The treatment of pandemic problems has not always escaped such thorny issues.
\end{abstract}

\section{Keywords}

The good of the person. The common good. Conscientious objection.

\section{Resumen}

Tres temas ocupan el espacio de esta presentación. Los dos primeros abordan el mismo problema, pero desde un ángulo diferente. La relación entre el bien personal y el bien común puede de hecho ser objeto de al menos dos discursos diferentes, el de la ética y el del derecho. Además, puede parecer extraño vincular estos dos temas con un tercero, reservado a la objeción de conciencia. Sin embargo, esto es válido porque constituye, a nivel de ciudadanía, una forma sociopolítica de tensión entre un bien personal y un bien común, de carácter social o político. De esta forma, la ética, el derecho y la ciudadanía política interfieren cuando queremos abrir el proceso de relaciones entre el bien personal y el bien común. El tratamiento de los problemas pandémicos no siempre ha escapado a cuestiones tan espinosas.

\footnotetext{
${ }^{1}$ Professor Catedrático, Universidade Nova de Lisboa, Liège, Bélgica. E-mail: michelmrenaud@gmail.com
} 


\section{Palabras clave}

El bien de la persona. El bien común. La objeción de conciencia.

\section{Introdução}

A pandemia devida ao aparecimento da COVID-19 ou SARS-CoV-2 surpreendeu todos os países pela gravidade das suas consequências nefastas: em primeiro lugar, o sofrimento dos doentes e sobretudo a perda de numerosíssimas vidas humanas; a seguir, a escassez dos meios terapêuticos e de prevenção inicialmente disponíveis, a angústia diante de um contágio fulgurante, o isolamento devido ao confinamento necessário, a impossibilidade de acompanhar os familiares e amigos no seu fim de vida e de lhes prestar a desejável homenagem após a sua morte, a paralisia da vida económica, social e cultural, o drama das pessoas que ficam sem meios de subsistência ou vêem desmoronar-se a viabilidade da sua empresa. É impossível ainda medir as consequências da praga que está a atingir toda a humanidade. A estes fenómenos acrescenta-se o sacrifício dos que se dedicam integralmente aos cuidados de saúde nos hospitais, aceitando correr riscos tais que, efectivamente, não poucos - médicas e médicos, enfermeiras e enfermeiros, assim como outros prestadores de cuidados de saúde - sucumbiram no serviço ao qual, de modo heróico, dedicaram a sua vida. Também é preciso louvar e agradecer todos os que prestam serviços indispensáveis à permanência de uma certa normalidade nas condições da nossa vida social.

Contudo ainda não conseguimos medir as consequências culturais e civilizacionais que esta pandemia vai deixar atrás de si.

Neste panorama sombrio é compreensível que novos desafios de natureza ética e bioética surjam tanto na comunidade humana geral como nos hospitais e em todas as instituições de saúde. Aliás, em muitos países, Comités de Bioética já redigiram documentos e pareceres aprofundados sobre a vida social e hospitalar no contexto da COVID-19. Contudo, convém alargar o campo de visão dos problemas e, por isso, praticar um certo recuo para retomar alguns problemas de fundo, sempre subjacentes quando um grave acontecimento faz tremer as bases da nossa sociedade. Tal é a tarefa da análise filosófica na qual se inscreve esta apresentação. Com efeito, a pandemia oferece uma ocasião para revisitar algumas das questões que se perfilam quando se trata do bem pessoal e do bem comum. 
Três temas ocupam o espaço desta apresentação. Os primeiros dois debruçam-se na mesma problemática, mas sob um ângulo diferente. A relação entre o bem pessoal e o bem comum pode efectivamente ser objecto de pelo menos dois discursos diferentes, o da ética e o do direito. Além disso, poderá aparecer estranho ligar a estes dois temas um terceiro, reservado à objecção de consciência. Mas este tem cabimento aqui na medida em que constitui, ao nível da cidadania, uma forma política de tensão entre um bem pessoal e um bem comum, de natureza social ou política. Desta maneira, ética, direito e cidadania política interferem quando queremos abrir o processo das relações entre o bem pessoal e o bem comum. O tratamento dos problemas da pandemia não escapou a tais questões espinhosas.

\section{O bem da pessoa e o bem comum à luz da ética}

Não se pode referir o bem sem abrir o portão da ética. Por isso mesmo, a primeira parte desta análise abrange a relação entre o bem da pessoa e o bem comum apreendidos num sentido ético. Dado que a totalidade deste trabalho foi feito numa perspectiva filosófica, esta parte será mais desenvolvida que a segunda, centrada no aporte do direito.

O primeiro passo útil, antes de entrar nesta relação propriamente dita, consiste em lembrar o que é a ética. Na multiplicidade das definições existentes, privilegiar-se-á a de Paul Ricoeur, apresentada no seu grande livro de antropologia filosófica em 1990, Si próprio como um outro (1). Este livro, que trata das relações entre a identidade pessoal e a alteridade humana, comporta nos seus penúltimos três capítulos um minitratado de ética, isto é, os lineamentos do pensamento ético em aproximadamente cento e cinquenta páginas. Nele encontramos a definição que em largos ambientes universitários se tornou a melhor definição da ética. Numa frase, Ricoeur sintetiza esta definição da seguinte maneira: "a ética é a procura da 'vida boa', com e para os outros, em instituições justas". Dedica então um longo comentário a esta definição, que, condensada em três breves membros, aparece ainda bastante formal. A principal observação que reteremos dela reside na diferença entre o segundo e o terceiro membro, que juntos desdobram a alteridade de que se trata. No segundo membro - com e para os outros - a pluralidade refere-se ao círculo estreito ou largo das pessoas que cada um conhece, conheceu, continuando a poder eventualmente encontrar, assim como aos que no futuro farão parte do seu meio familiar, social e profissional. Pelo contrário, o terceiro membro - em instituições justas - situa todas as pessoas que cada pessoa que diz eu nunca vai conhecer ou que se fundem no anonimato 
dos grupos de que conhecemos talvez a existência, assim como de todas as comunidades de que cada um faz parte, desde a comunidade nacional até à comunidade mundial.

Desta maneira, na ética entra também a relação com todo o ser humano, relação não imediata, mas mediatizada pelas instituições, desde a instituição dos grupos intranacionais aos transnacionais, coroados pela Organização das Nações Unidas (ONU), enquanto organização mundial. Ora, para todas as instituições a virtude primordial é a justiça. Noutros termos, o primeiro sentido da justiça é de natureza ética, antes de se fixar como justiça jurídica - dir-se-á apesar do pleonasmo implícito da expressão - e de culminar na justiça política. A justiça nas instituições micro ou macroscópicas faz essencialmente parte da ética, tal como reconheceram desde os primórdios do pensamento filosófico Platão e Aristóteles. Neste pano de fundo apresenta-se a relação entre o bem pessoal e o bem comum, relação que assume as figuras opostas de uma divisão, mas também de uma força unitiva.

O segundo passo deste percurso leva à caracterização do bem da pessoa e do bem comum, na perspectiva da filosofia, antes de esboçar a sua diferença com a do direito. O maior bem para a pessoa singular consiste em realizar uma existência boa, a vida boa de que fala a definição da ética. Desde Platão e Aristóteles a problemática do bem está no centro da reflexão. Existe uma multiplicidade de bens, o que exige um esforço de clarificação. Os bens que ajudam o ser humano a manter-se vivo são bens sem os quais não haveria vida possível, são bens sine qua non, isto é, fisicamente necessários. Neste sentido, o primeiro bem é o dom da vida, o nascimento. Deve-se à Hannah Arendt uma reflexão sobre o sentido do nascimento, que vai além da celebração dos aniversários (2). Todos os bens materiais que contribuem para manter a vida, em todas as suas dimensões, fazem parte da busca da realização humana. Contudo, dotado de uma liberdade, liberdade não total, mas finita, o ser humano deve pôr-se a caminho do sentido da sua existência. Este sentido, que não está dado à partida, é precisamente a tarefa da existência construí-lo e conquistá-lo. Deste ponto de vista, prosseguimos no dia a dia um leque de bens particulares, inerentes à educação, ao trabalho profissional, à cultura, assim como à fé para quem a tem; graças à realização destes bens, susceptíveis de serem hierarquizados, configura-se concretamente a existência pessoal. O bem ético é a dimensão unificadora dos bens concretos, assemelhando-se à seta dinâmica que os atravessa em vista à realização do sentido da existência. O conteúdo concreto do bem ético será a maneira como cada pessoa consegue determinar o sentido mais unificador da sua existência mediante as escolhas que realiza, senão em cada dia, pelo menos nas várias fases da sua vida; de modo mais preciso, será a 
A finalidade específica do político consiste, por um lado, no fortalecimento das relações exteriores, o que corresponde à segurança e à protecção de Hobbes e, por outro lado, na manutenção da ordem e no estabelecimento de condições de vida razoáveis, o que corresponde à paz interior na prosperidade em Hobbes. (5)

Interessa notar que na filosofia política o bem comum incorpora qualidades éticas por excelência, começando pela justiça, que, como acaba de ser referido, a tradição moderna interpreta de modo diferente. Pode-se também sublinhar que num passado recente, dois tratados de filosofia política renovaram com muito interesse a problemática da justiça política, A theory of Justice de John Rawls (6), ao qual se contrapõe A Idea of Justice (2010) de Amartya Sen (7).

Se devêssemos sintetizar a relação entre o bem pessoal e o bem comum, poderíamos caracterizar o primeiro como a realização ética da dignidade humana e este como a realização ideal da convivência humana. Esta breve formulação merece um complemento de análise, respectivamente sobre a dignidade e a convivência.

O valor mais compreensivo da pessoa é a sua dignidade, conceito central e de difícil definição. Por um lado, a dignidade constitui-se como um dado ontológico, no sentido em que é coextensiva ao ser da pessoa. Por outro, ela vive-se eticamente, na medida em que é portadora de uma exigência de realização.

Com efeito no seu ser (isto é, do ponto de vista ontológico), a pessoa humana nunca perde a sua dignidade; esta está-Ihe indissociavelmente ligada, qualquer que seja o carácter repreensível dos seus actos. Aliás, a recusa da pena de morte encontra o seu único fundamento nesta dignidade ontológica. Contudo, estamos perante um círculo, que ilustra bem a evolução das ideias filosóficas. Por um lado, é a dignidade humana que exige um comportamento ético que lhe corresponda. Por outro, o que faz compreender a dimensão ontológica desta dignidade é o olhar ético que se encontra perante uma espécie de imperativo, isto é, afirmar a presença inalienável da dignidade humana.

Este círculo teve dois estilos de fundamentação diferentes, o primeiro de natureza teológica: se todo o ser humano é criatura de Deus, nunca pode perder este estatuto. Mas nas sociedades laicas, em que não se pode impor a ninguém a adesão a um credo religioso, é preciso um outro tipo de fundamentação da dignidade ontológica da pessoa. Kant e Levinas podem ser considerados como dois filósofos mais promotores desta tese.

Deixando de lado Levinas, que mereceria largas explicações, fixaremos apenas que, para Kant (8), a dignidade humana significa que o ser humano é definido como sendo um 
fim-em-si; noutros termos, a finalidade da existência humana reside no próprio ser humano e não lhe pode ser retirada, sob pena de o transformar em escravo. Com efeito, a finalidade do escravo está nas mãos do seu dono, que transforma em instrumento o ser escravizado. Ora, sendo fim-em-si, o ser humano, por definição, não pode ser instrumentalizado nem escravizado.

Evidentemente, isto não significa que a pessoa se torne escrava pelo facto de ser contratada para prestar serviços profissionais ou outros. Pelo contrário, é a vocação humana participar na construção da sociedade. Em vez de a tornar escrava, os serviços, profissionais ou outros, em prol do bem comum dignificam a pessoa que os presta. A diferença reside na distinção entre a instrumentalização do ser e a prestação de serviços pelo agir da pessoa. Pelo nosso agir que presta servições, dependemos da empresa que nos contrata, não para se apropriar do nosso ser, mas para pedir prestações no campo do agir. Quando esta dependência ultrapassa estes limites, vira-se para a perversão, ao introduzir novas formas, subtis ou patentes, de escravatura. Infelizmente o mundo actual conhece numerosos casos desta perversão.

Poder-se-ia perguntar como é que Kant fundamenta a tese de finalidade-em-si da pessoa. Sigamo-lo em breves palavras. Em virtude do seu carácter irrepetível, a pessoa não tem preço, dado que o preço se estabelece sempre em função de uma comparação com coisas de mesma natureza. Desta maneira, aquilo que não tem preço tem uma dignidade; a expressão desta dignidade vive-se na autonomia ética que decorre da finalidade-em-si da pessoa. Com efeito, a autonomia não significa fazer o que se quer, mas obedecer à razão, a qual é o específico do ser humano; portanto, é a referência à autonomia como capacidade de se dar a si mesmo a lei que justifica ontologicamente a finalidade-em-si do ser humano e, por conseguinte, a sua dignidade.

De modo mais rigoroso, os conceitos encadeiam-se do seguinte modo: a razão, no seu uso prático, é o apanágio do ser humano; da razão procede a autonomia, enquanto capacidade de o ser humano se dar a si próprio a lei moral (sem a razão, o ser humano seria governado pelos seus instintos e pela sua mera sensibilidade, como o animal). A auto-nomia justifica a finalidade-em-si, na medida em que o autos humano (si próprio, em grego) é a finalidade global do seu próprio desenvolvimento. Da finalidade-em-si decorre então a unicidade singular da pessoa, a qual tem como consequência a não comercialização da pessoa. A unicidade irrepetível da pessoa é o que se exprime como dignidade, termo final 
da cadeia conceptual. Notemos que esta cadeia é circular, na medida em que são estas mediações que juntam a dignidade humana à presença da razão prática no ser humano.

Por isso mesmo, do ponto de vista da dignidade humana, todas as pessoas têm direito ao mesmo respeito básico e fundamental pela sua vida, enquanto membros da comunidade humana. Este direito ultrapassa todas as diferenças bem conhecidas (raça, sexo, orientação sexual, saúde, idade, opiniões políticas, crenças religiosas, etc.), de tal modo que o valor da dignidade humana não é, portanto, nem alienável nem negociável e constitui o supremo bem pessoal.

Quanto ao bem comum, apreendido de modo ético mais do que jurídico, ele tem como finalidade a saudável convivência humana; esta realiza-se graças à qualidade ética principal das instituições, que já foi apresentada como a justiça. Que a justiça se concretize pela paz externa com os inimigos e pela ordem interior da comunidade nacional, manifesta a transição operada pela filosofia na época moderna, mas não altera o sentido ético primordial do bem comum.

A esse respeito, na esteira de Gaston Fessard (9), autor de um valioso livro sobre autoridade e bem comum, Roque Cabral pormenoriza a sua abordagem ética do bem comum:

O bem comum compreende um conjunto de bens (não apenas materiais) equitativamente participáveis por quantos se associaram precisamente para os promover e participar em comum. Tais são os três aspectos ou categorias que a análise distingue, com Gaston Fessard, na complexa realidade do bem comum: o "bem da comunidade" (os bens por ela possuídos de facto), a "comunidade desse bem" (o direito de todos a participarem equitativamente dele), o "bem de comunhão" (o valor que a todos une, mais fundamentalmente do que aquilo que os divide). (2)

Esta terceira característica é muitas vezes subentendida, mas a sua falta gritante aparece dramaticamente quando numa comunidade nacional, uma região quer fazer secessão (é actualmente o caso com a Catalunha na Espanha).

Do ponto de vista ético, podemos concluir que existe uma estreita relação entre a singularidade do bem pessoal, a pluralidade do bem comum, antes de mais, inerente à justiça que preside às instituições subordinadas a conjuntos mais vastos, e finalmente a totalidade do bem comum coextensivo à comunidade humana global, desde as comunidades nacionais até às organizações internacionais. Ora, se o bem pessoal se manifesta como busca de felicidade no respeito pela dignidade humana, de si próprio e dos outros, se o bem da pluralidade se baseia primordialmente na justiça das instituições, o bem comum da 
comunidade mundial começa pelas condições que perpetuam a viabilidade da existência humana na terra.

Desde o século XX estamos mais atentos ao bem comum da comunidade mundial, que se encontrou sob a ameaça e o desencadeamento de guerras mundiais. Estas, tal como as guerras que se seguiram, fizeram e fazem sentir na pele que a paz é o primeiro valor do bem comum mundial. Contudo, hoje temos a consciência viva de que o valor da paz está indissociavelmente ligado à solidariedade entre as nações. Com efeito, não há paz sem uma activa solidariedade mundial, principalmente quando já não são unicamente as guerras que constituem as mais largas ameaças ao bem comum, mas além da pandemia, os desequilíbrios ecológicos, que fazem correr à humanidade perigos de que ainda não podemos imaginar a gravidade. Talvez pela primeira vez na história humana, a sobrevivência do bem comum pessoal, político e universal depende também da capacidade humana de preservar, como bem mostrou Hans Jonas (10), desde 1979, as condições de possibilidade da própria vida humana na terra. O valor da paz, que parecia constituir o âmago do bem comum mundial, exige agora, mais do que nunca, o seu corolário imediato, a solidariedade. Se a fraternidade humana pode ser, de modo metafórico, o lema das relações éticas mundiais, como propõe a encíclica Fratelli tutti do Papa Francisco (3), a transposição da fraternidade para o bem ético comum mundial consiste na solidariedade entre as nações. $A$ este respeito, quando se olha para a relações internacionais mundiais. verificamos que a força política, militar e económica ainda triunfa nelas, prolongando o reino da selva na terra, embora sinais de solidariedade entre as nações tenham começado a dar resultados dignos de estimular a esperança. De todo o modo, paz e solidariedade presidem ao bem comum mundial, envolvendo a busca do bem pessoal e a procura da justiça nas instituições.

A pandemia estimulou consideravelmente a atenção ética pelo bem comum, não apenas pela generalização do medo que inspirou e da similaridade das medidas de confinamento que paralisaram as populações, mas também graças aos exemplos admiráveis e às vezes heróicos que suscitou. Na hora presente, mais de 17 mil prestadores de cuidados de saúde, médicas e médicos, enfermeiras e enfermeiros, técnicas e técnicos pagaram com a vida o seu combate contra o vírus, dando um exemplo inesquecível de profissionalismo, dedicação, abnegação e generosidade. Foram e são os combatentes de primeira linha neste novo estilo de guerra. Encarnaram mais do que a justiça e a solidariedade; foi com efeito uma solidariedade fraterna, uma autêntica caridade. 


\section{O bem pessoal e o bem comum à luz do direito}

A abordagem ética das relações entre o bem da pessoa e o bem comum deve confrontar-se com a sua tematização jurídica. Será que existem muitas diferenças entre o bem pessoal e comum analisado pela ética e a sua compreensão pelo direito? Vale a pena pôr-se à escuta das ideias propostas por António Barbosa de Melo, professor de direito e antigo presidente do Parlamento português; em poucas páginas traçou linhas muito esclarecedoras a este respeito. O que interessa aqui é a maneira de estruturar esta reflexão. Na primeira parte, o eminente jurista interroga a "relativa autonomia entre o Direito [por um lado] e a Moral (Ética e religião) [por outro]" (11, p. 25-35). O que já chama a nossa atenção neste título é o segundo pólo da ligação, a Moral, que inclui a ética e a religião. Esta junção significa que ética e religião são sistemas normativos, mas não uniformes, fazendo parte da realidade normativa transjurídica. Trata-se então de discernir o papel do transjurídico na fundamentação do bem pessoal e do bem comum, sendo aqui a ética e a religião duas expressões deste transjurídico que transborda o campo do direito.

Neste modelo do positivismo do direito, reconhecer-se-á a figura de Hans Kelsen (12), em A teoria pura do direito (na sua segunda edição, de 1960). No fim de contas, o positivismo jurídico procura compreender o normativo em si mesmo e não como apoiado em valores morais ou religiosos. É por isso que o seu ponto inicial reside numa norma fundamental (Gründnorm), a compreender como um enunciado hipotético justificando o carácter normativo da norma.

Desta maneira, o direito positivo justifica a sua autonomia, dissociando-se da ética e da religião, enquanto conteúdos de valor. O sistema jurídico tem que ser coerente, de tal modo que cada norma inferior não possa contradizer uma norma superior. Para Barbosa de Melo, o direito positivo aparece como um "sistema fechado, auto-suficiente e portador de soluções paras todas as questões ocorrentes na vida social (postulado da plenitude lógica da ordem jurídica)" (11, p. 27). O que interessa aqui não é a exposição da tese de Kelsen, mas a conclusão que Barbosa de Melo tira dela para o bem pessoal e o bem comum. Contrariamente à compreensão ética ou religiosa, "as noções de bem pessoal e de bem comum hão de ser entendidas sempre nos termos em que o direito positivo as definir" (11).

Vários autores concluem, contudo, que não é possível manter a coerência desta norma fundamental sem a justificar por elementos que escapam à lógica imanente do positivismo jurídico. Sem discutir esta crítica, somos reenviados para a hipótese contrária à da absolutização do positivismo jurídico; é então o jusnaturalismo que se apresenta. 


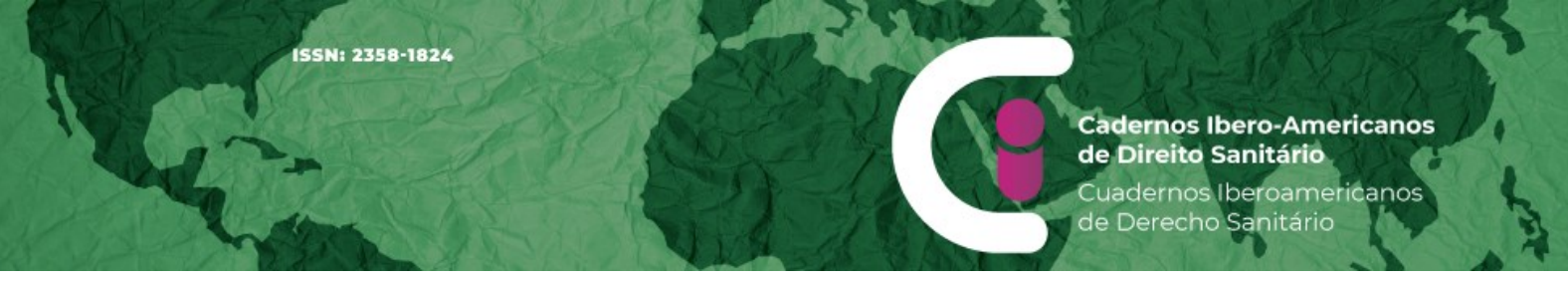

Qual é a orientação que o direito natural imprime à fundamentação do direito positivo? Diremos numa palavra que se recorre a valores éticos ou mesmo religiosos para fundamentar a validade absoluta da normatividade jurídica. Esta tese tem as suas raízes na filosofia grega e os seus ramos propagaram-se até além do marxismo. Oiçamos a síntese que Barbosa de Melo faz dela:

A verdade é que, desde os gregos, a tradição jusnaturalista - tomada no seu sentido mais amplo e por certo carregado de ambiguidades - alimenta o sonho, sempre renovado, da subordinação da ordem jurídica positiva - lex temporalis - a uma ordem jurídica transpositiva, fundada em Deus, na razão, na natureza, em valores e estruturas ético-materiais ou, desde o século XIX (Marx), nas estruturas produtivas [...]. (10)

Por conseguinte, "o direito não seria senão uma mera tradução dessa ordem normativa superior ('o direito natural')". (11)

Qual é então a consequência para a compreensão jurídica do bem pessoal e do bem comum? Resulta que "o bem pessoal e o bem comum hão de ser definidos em princípio, por aplicação das normas e critérios éticos ou religiosos - como será à luz das mesmas normas e critérios que haverão de ser reconhecidas e superadas as tensões entre ambos". (11, p. 28)

Numa página na qual se delineia perfeitamente o movimento das ideologias do século $X X$ até aos nossos dias, o autor mostra que a absolutização do direito natural leva à justificação das teocracias, que depois do seu declínio desde a eclosão da época moderna, voltam a aparecer no nosso mundo sob a forma de fundamentalismos religiosos.

A apresentação que Barbosa de Melo faz destas duas teorias podia rivalizar com as dialécticas hegelianas da Fenomenologia do Espírito (13). A única alteração necessária consistiria em pôr o jusnaturalismo como posição primordial (a tese), e o positivismo jurídico como contraposição (a antítese). Qual pode ser então o terceiro momento, o da superação da dialéctica?

No caso desta discussão entre direito natural e direito positivo, o elemento mediador, por Barbosa de Melo, deve ser a aceitação de alguns "núcleos de princípios indisponíveis", que constituiriam "'um mínimo ético' inerente à ordem jurídica positiva" (11). A dignidade da pessoa humana estaria no centro deste núcleo. Acrescento que é por este motivo que os Direitos Humanos, que se baseiam sempre ou quase sempre na dignidade da pessoa, não conseguem prová-la juridicamente; com efeito, a sua aceitação exige uma compreensão e uma adesão puramente éticas. 


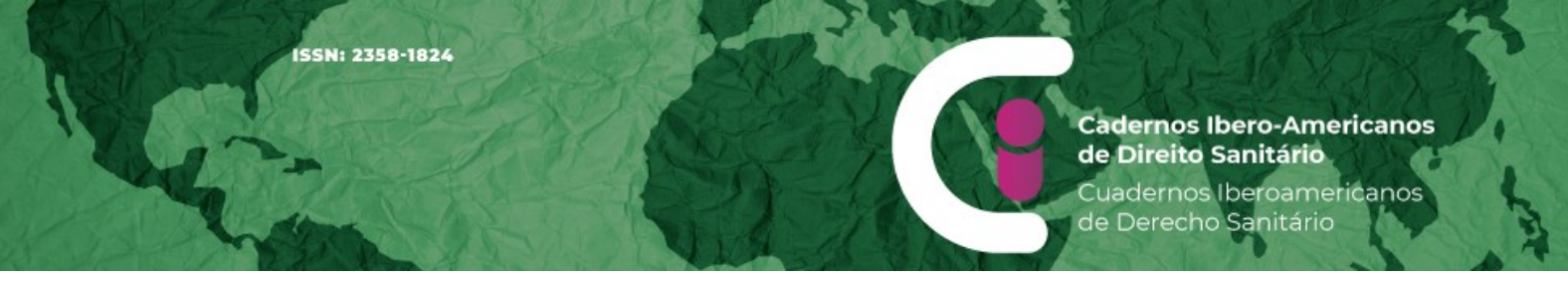

Seria demasiado longo expor a resposta de Barbosa de Melo quanto a esta superação jurídica das duas posições assinaladas. Mas, em meu entender, o coração das suas considerações retoma, com uma linguagem mais jurídica, a necessidade da intervenção da sabedoria prática, no sentido em que Ricoeur (1) a desenvolve na sua ética. De modo sucinto diremos que mais do que uma conciliação teórica e fixada de uma vez por todas, é preciso entrar em diálogo com as condições concretas e sobretudo com os interesses em presença, que estão à espera da resposta jurídica. Tal é o sentido do subtítulo $A$ fuga para o institucional e procedimental. Concluiremos este parágrafo sobre a perspectiva jurídica com uma última citação, muito clara, de Barbosa de Melo (11). Deve-se

procurar estabelecer condições adequadas à descoberta de uma decisão suficientemente racional $(H$. Simon) (13), porque credenciada em valores e princípios jurídicos, ética e socialmente aceites, institucionalizando processos de consulta e de deliberação virados, menos para a descoberta de razões objectivas permanentes e mais para a obtenção dos consensos circunstanciais indispensáveis à paz social. (10, p. 31-32).

É desta maneira que o autor considera que é melhor abandonar as teses demasiadas fixas, que ele chama "plano material ou substancial" em provento do "procedimental e institucional".

\section{A objecção de consciência, entre a ética e a cidadania política}

A objecção de consciência situa-se na intersecção entre a ética e a cidadania política. Daí surge a questão: neste confronto, a quem pertence a prioridade, à ética ou à política? Mas o que se entende por prioridade, uma vez que não se trata de uma escolha deixada ao arbitrário de cada um? Falar de prioridade não significa uma qualquer prestação de homenagem de uma à outra, mas a determinação do critério destinado a resolver um conflito que surge entre uma lei política politicamente promulgada, que requer a obediência, e os valores sem os quais a pessoa individual considera que a sua vida perde algo da sua dignidade ética. Este enunciado geral exige, contudo, uma multiplicidade de precisões para ser devidamente compreendido.

Em primeiro lugar, é necessário indicar que espécie de Estado está aqui em foco. Uma das principais características do estado democrático consiste em não querer impor uma determinada visão ou visée do bem ético. Noutros termos, o Estado democrático assume a decisão de deixar a cada cidadão a tarefa de encontrar o sentido primeiro e último da sua existência. O Estado pode estimular valores que ele considera como fazendo parte do 


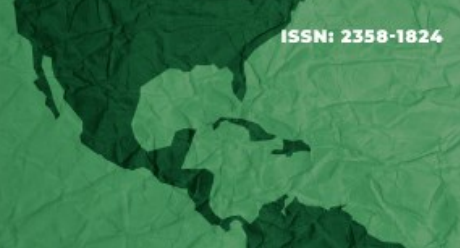

património cultural da nação ou das suas nações, mas não obriga ninguém a viver os valores que não estão estritamente codificados no seu direito positivo. Em sentido contrário, o Estado totalitário tenta impor a sua compreensão do bem e para este efeito reduz o mais possível a esfera da vida privada, controlando do modo mais subtil o pensamento dos seus sujeitos. Um Estado com um partido único implica em geral uma única maneira de pensar, não apenas do ponto de vista político, mas também na esfera da ética na qual se joga, em último lugar, o destino existencial de cada um. Em geral, o Estado totalitário não prevê a possibilidade legal da objecção de consciência.

O direito à objecção de consciência é, portanto, uma aquisição devida ao estado democrático, que se autolimita quanto à imposição da obediência às leis que promulga. É na base destas notas prévias que se deve analisar hoje a natureza do conflito subjacente à objecção de consciência.

Antes de entrar em outros elementos de análise, não será supérfluo evocar um dos primeiros conflitos que na cultura do Ocidente surgiu entre política e ética, isto é, a tragédia Antígona de Sófocles (15). Lembramo-nos da história: dois irmãos filhos de Édipo lutam pelo governo da cidade de Tebas e morrem em combate. O irmão que militava a favor das leis da cidade teve direito aos ritos fúnebres que lhe assegurariam a vida no além, ao passo que o outro, tendo tido a vontade de derrubar o poder legítimo, não devia ser enterrado, mas deixado como presa dos abutres, sem direito ao condigno funeral. Tal era a ordem estabelecida na Cidade por Creonte, o tio e tirano. Antígona infringe a ordem de Creonte e de noite procede ao enterro do irmão, por fidelidade àquilo que considera como a lei não escrita, mas inscrita no seu coração. O acto de desobediência chega ao conhecimento do tirano, que decreta a morte de Antígona, noiva do seu filho. O emparedamento vivo e a morte de Antígona provocam o suicídio do noivo e o arrependimento de Creonte, mas tarde demais para evitar a ruína da família.

Nos admiráveis diálogos entre Antígona e a sua fraca irmã Ismena, assim como entre Creonte e Antígona, tece-se a trama trágica dos heróis. Citemos apenas duas passagens célebres da Antígona: "É mais longo o tempo que devo agradar aos que estão no além do que aos que estão aqui" (15, v 76);

É que essas [leis] não foi Zeus que as promulgou; nem a Justiça, que coabita com os deuses infernais, estabeleceu tais leis para os homens. E eu entendi que os teus éditos não tinham tal poder, que um mortal pudesse sobrelevar os preceitos, não escritos, mas imutáveis dos deuses. (15, v. 450) 


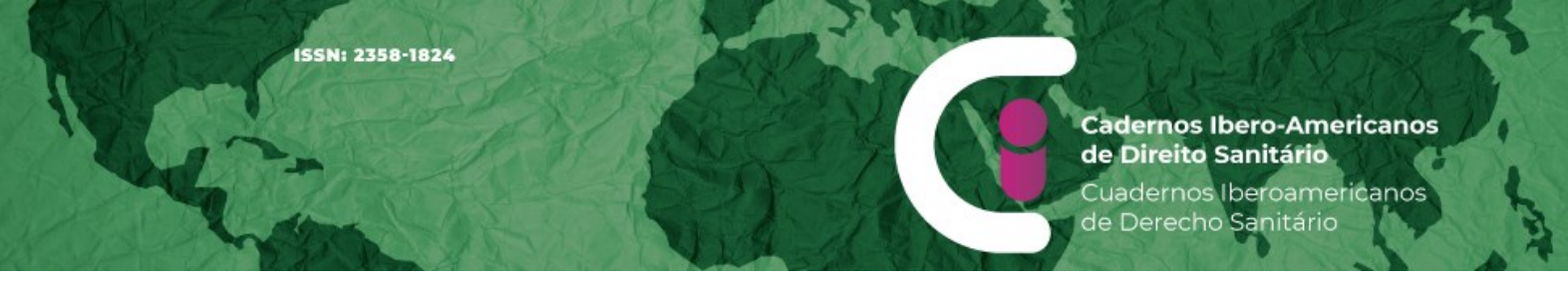

Esta tragédia deu origem a uma quantidade inumerável de comentários. As leis não escritas, mas presentes no coração são as do direito natural, disseram muitos clássicos; e a lei natural ou o direito natural tem sempre prioridade sobre o direito positivo. Outros comentários irão num outro sentido. Por exemplo Hegel, na Fenomenologia do Espírito (13), denuncia a unilateralidade das duas atitudes; unilateralidade à qual faz eco o comentário de Paul Ricoeur:

É preciso concordar com Hegel e dizer que a visão do mundo de Antígona não é menos estreitada e subtraída às contradições internas que a de Creonte. [...] São efectivamente duas visões parciais e unívocas da justiça que opõe os protagonistas. A estratégia de simplificação, como diz Nussbaum [...] não torna Antígona menos inumana que Creonte. $(1$, p.284)

Mas além dessas simplificações, deve-se reconhecer que

a tragédia de Antígona incide naquilo que, na esteira de Steiner, se pode chamar o fundo agonístico da provação humana, na qual se confrontam interminavelmente o homem e a mulher, a velhice e a juventude, a sociedade e o indivíduo, os vivos e os mortos, os homens e o divino. (15)

Esta linha de pensamento mostra que a tragédia de Antígona reflecte uma maior amplidão que não o tema único da objecção de consciência. Esta dilatação convida-nos a desvendar alguns traços comuns a todos os casos de objecção de consciência.

A objecção de consciência, com efeito, apresenta-se como uma decisão governada por motivações exclusivamente éticas. Mas não é isso que lhe garante a sua neutralidade política; neste sentido, não existe uma objecção de consciência totalmente isenta de impacto político. O propósito da sua neutralidade política é, portanto, uma ilusão; o caso de Gandhi ilustra-o suficientemente, uma vez que a sua não-violência se apoiava num projecto político consciente e explícito. Notemos, em sentido contrário, que Gandhi ficou vivo porque a potência inglesa que ele desafiava não o eliminou fisicamente, o que, por exemplo, teria sido o caso se ele tivesse vivido no tempo dos gulags de Estaline. Um objector de consciência como o francês Lecoin, na véspera da segunda guerra mundial, propunha que a França se deixasse invadir pela Alemanha; o resultado da sua posição foi a cadeia. Não vamos passar em revista, contudo, a história empírica da objecção de consciência; apenas lembraremos que a literatura a seu respeito se limitou durante muito tempo e quase unicamente à vida militar. É num passado relativamente recente que o campo dos cuidados de saúde passou a ocupar um lugar de destaque nesta problemática. 
As considerações que se seguem tencionam discernir de mais perto a natureza da objecção de consciência. Três alternativas cruzam-se que merecem a nossa atenção. 1) Trata-se de recusar obedecer a uma lei positiva que não admite excepções ou a uma lei que prevê o recurso à objecção de consciência?; 2) O valor ético que está em causa na objecção de consciência está relacionado com um princípio universal, considerado como fazendo parte do direito natural, ou diz respeito a uma opção particular do objector, por exemplo, no foro das suas crenças religiosas, face ao direito positivo?; 3) Em seguida, será que se pode considerar como objecção de consciência a recusa de obedecer a uma ordem considerada como perversa de um superior hierárquico?

Apresentemos exemplos. No último caso citado, está-se na presença de uma ordem pontual imoral, por exemplo, a obrigação emitida por um superior de fazer assinar pelo seu subordinado um determinado cheque, o que corresponderia a um acto de corrupção activa. Será que a recusa de assinar coloca o subordinado na situação de objector de consciência? Por um lado, sim, na medida em que ele invoca um valor ético que não quer lesar. Mas por outro lado, a ordem é particular e dá origem, neste contexto preciso, a um acto imoral e ilícito, um acto cuja ilicitude é implícita ou explicitamente suposta pelo direito positivo. A recusa do subordinado entra, portanto, no campo das acções éticas, eventualmente heróicas, que se mantêm no foro das relações particulares. É só num sentido metafórico que se poderá falar de objecção de consciência; ela consiste, com efeito, na recusa, por motivos éticos, de participar num acto privado ilícito.

A primeira alternativa referida evocava o caso da desobediência a uma lei que não admite excepções ou derrogações. Neste caso o objector sabe que se expõe à repressão legal e às sanções previstas para tais casos. Será que a morte de Sócrates pertence a esta categoria? Sim e não, teremos de responder; Sócrates foi condenado sob o pretexto de ir contra a lei ao corromper a juventude, embora não estivesse de acordo com esta acusação. Negou, portanto, ter cometido um acto que violava a lei. Por outro lado, ele quis mostrar que as leis vigoram e que devem ser respeitadas; por isso mesmo, em vez de fugir, ele obedeceuIhes aceitando beber a cicuta. Não rejeitou a lei, mas tinha consciência da injustiça da sua condenação. Próximos da situação de Sócrates foram os casos de alguns dissidentes soviéticos, tais como Sakharov e, mais recentemente, de Navalny desafiando o Presidente Putin. Eles tomaram posição em nome da verdade e da justiça, sabendo que teriam de aguentar as consequências dos seus actos. 
A diferença entre Sócrates e os dissidentes russos é que Sócrates obedeceu a uma lei injusta, ao passo que os dirigentes russos consideram que se trata, a seu respeito, de uma violação das leis existentes, tratando-se, portanto, de casos pontuais, embora repetidos, de perversão política. Neles, a finalidade política do seu acto ético era consciente, intencionalmente prosseguida, num diálogo de forças, embora com armas diferentes das do poder político. Esta situação aproximava-os do caso de Gandhi.

Abordemos o segundo caso citado, isto é, as situações mais frequentes na nossa cultura democrática, nomeadamente aquelas nas quais a objecção de consciência é prevista e permitida pela lei. As leis sobre o abortamento - IVG - entram nesta categoria. Esta temática foi objecto de uma análise estimulante de Diego Gracia $(17,18)$, director e co-autor do livro Ética da la objeción de conciencia, que merece ser comentada. Notemos que este livro tem uma multiplicidade de autores, indicados no princípio, mas não identificados no índice do livro; portanto não sabemos se as ideias aqui discutidas são exactamente da autoria de Diego Gracia (embora as tenha feito suas) ou de um dos seus colaboradores. Pela facilidade da escrita, refiro o livro como sendo do seu Director, Diego Gracia, embora a ideias discutidas possam ser da autoria de um dos seus co-autores.

Com ele podemos partir de uma análise dos juízos éticos. Gracia $(17,18)$ retoma a formulação de David Ross, grande comentador de Aristóteles, ao distinguir, no campo do agir, os imperativos categóricos (prima facie duties) e os imperativos hipotéticos (actual duties). Com Aristóteles, Ross (19) reconhece justamente que o agir nunca se realiza num contexto de evidência, de certeza e de previsão clara do futuro e das consequências da acção. A este respeito, prefiro a formulação de Paul Ricoeur (1) que reconhece que os princípios éticos do agir exigem, na sua aplicação, a sabedoria prática para se tornarem adequados às circunstâncias sempre particulares do contexto da acção. Mas a análise de Gracia $(16,17)$ continua, em meu entender, de modo estranho. A objecção de consciência, afirma, implica um conflito de valores: o valor da lei que provém do consenso democrático e que tem legitimidade, por um lado, e as convicções particulares do objector de consciência, por outro. Segundo Gracia, o objector não reconhece que existe um conflito entre dois estilos de valor, porque, para ele, o respeito pela lei entendida como eticamente injusta não pode ser considerado como um valor.

Niega valor a uno de los términos del conflicto. Lo qual demuestra algo de la máxima importância y sobre lo que raramente se llama la atención, a saber, que lo que el objetor niega es la legitimidad de la norma o de las normas em 
juego. En el fondo, la suya no es una objeción de acto sino de ley. $Y$ eso es lo que resulta incorrecto e inadmisible. $(17,18)$

Para nós, podemos dizer que isso não é uma novidade, uma vez que desde o princípio reconhecemos o impacto político de todas as objecções de consciência. Mas para Diego Gracia $(17,18)$, a atitude do objector acaba por tomar a forma de um "curso extremo de acción”. Ora, julga ele, os cursos extremos de acção foram desde Aristóteles reconhecidos como não sendo óptimos. Lesam com efeito um valor importante no conflito de valores que o objector quer resolver. É melhor então encontrar um "curso intermédio" que, no contexto da vida prática, tente harmonizar o mais possível os valores em oposição.

Concretamente, Gracia $(17,18)$ pensa no caso da lei do aborto, que ele cita logo à seguir como exemplo: o objector não tem razão, porque a lei tem legitimidade democrática e constitui deste modo um valor que o objector não pode ignorar; além disso, ao opor-se à lei, o objector opõe-se a uma lei que precisamente lhe permite e reconhece o seu estatuto de objector; ora "el objector no tiene capacidad ni autoridad para negar legitimidad social a un valor aceptado e consensuado por la mayoria de los ciudadanos" $(17,18)$. A conclusão de Gracia é que o curso intermédio da acção deve consistir em harmonizar e salvar o mais possível os valores em conflito. No exemplo do aborto, a lei não obrigará nenhum agente de saúde a realizar um abortamento, e as mulheres que querem beneficiar da possibilidade legal terão que aceitar ser encaminhadas para outros centros de saúde; por outro lado, o médico objector terá que realizar este aborto ao abrigo da lei "cuando no hay otro modo de asegurar la prestación”. Na base desta tese, Gracia $(17,18)$ considera que, nos casos desta natureza, a objecção de consciência é falsa, não respeitando as condições necessárias para poder objectar; trata-se, portanto, de uma pseudo-objecção, porque a lei prevê a possibilidade de não participar na acção em causa. Conclui que a maior parte das objecções de consciência no mundo da saúde, são efectivamente pseudo-objecções.

Confesso que esta argumentação não me parece convincente; julgo que se baseia num sofismo, embora esteja aparentemente adequada para o caso do aborto. Para o mostrar, empurremos o exemplo até ao limite. Imaginemos que a lei legalize o aborto sem motivo até à véspera do nascimento; admitamos também que esta lei tenha recolhido o consenso maioritário da população, mas aceite também não forçar nenhum médico ou enfermeiro a tomar parte num abortamento. Será que o "curso intermédio de acção", destinado a salvar o mais possível os valores em conflito, ainda neste caso teria validade? De certeza que não; o próprio Gracia $(17,18)$ admitiria que a conciliação já não é possível e 
que então, enquanto "curso extremo de acção", a objecção de consciência se justificaria. Mas esta afirmação entra em contradição com aquilo que o próprio Gracia enuncia: por um lado e seguindo a reflexão de Gracia, a lei do aborto livre até ao nascimento seria legal e democrática; mas ela seria ao mesmo tempo o veículo de uma grave falta ética e, deste modo, eticamente insustentável. Portanto, até a admissão legal de uma objecção de consciência seria insuficiente, face à integração, também legal, de uma grave lacuna ética. Então, o raciocínio de Gracia $(17,18)$ segundo o qual é preciso tentar harmonizar os valores em conflito, num "curso intermédio da acção" não resolve a maior parte dos casos de objecção de consciência. Noutros termos e contrariamente à posição de Gracia, existe a possibilidade de uma autêntica objecção de consciência à lei (ainda que a lei tenha codificado a sua possibilidade), porque o cerne da objecção diz respeito não a um caso individual e circunstancial de oposição à lei, mas à proclamação do carácter categoricamente não ético do seu conteúdo. Esta discussão deveria então abrir-se à historicidade dos grandes valores éticos; com efeito, estes não são estáticos, mas integram-se numa lenta história de progressos e, às vezes, de recuos.

O sofismo provém, em meu entender, do facto de pôr em pé de igualdade, numa equação a conciliar, um valor político e um valor ético. Noutros termos, quem deveria ser o árbitro da avaliação dos valores em presença (o valor da lei face ao valor protagonizado pelo objector) senão o avaliador que se centra no teor ético dos valores contidos na lei? É então que, em meu entender, aparece o erro dessa interpretação: Gracia $(17,18)$ opõe um valor formal de natureza política (a legitimidade da lei) a um conteúdo de valor de natureza ética (o valor da vida humana no seu começo). Esta oposição é apenas possível numa teoria para a qual é apenas o consenso politicamente democrático que está na origem dos valores éticos. Isto leva-nos, em meu entender, a confundir a formalidade da lei (entendida como valor democrático) com o seu conteúdo intrínseco, de teor ético. Isso caracteriza uma ética da discussão, à maneira de Habermas, mas também deixa entrever os seus limites. Será que estes limites nos reenviam para uma teoria jusnaturalista dos valores éticos, teoria que Gracia $(17,18)$ recusa como sendo incoerente? O propósito desta apresentação não permite abrir este debate. É por isso que, a título de conclusão, apresentamos apenas algumas considerações.

Em primeiro lugar é evidente que existem múltiplas formas de objecção de consciência, além da objecção de consciência na vida militar. Em seguida, toda a objecção de consciência relativamente a um decreto do direito positivo tem um impacto político. 
Contudo, este impacto político não deve ser entendido de modo quase revolucionário ou não democrático, como se o objector quisesse revogar a lei por meios não legais. Em terceiro lugar, no conflito entre a legitimidade formal de uma lei e o conteúdo de um valor ético, a lei terá que preservar a possibilidade de viver este valor ético, com a tripla condição de não lesar terceiros (como é o caso na mutilação genital feminina), de respeitar a dignidade humana (contra os abusos das teocracias e dos fundamentalismos) e de manter a separação dos poderes assim como a diferença entre vida privada e vida pública, na medida em que, tal como se lembrou no princípio desta terceira parte, não pertence à política democrática impor aos cidadãos o sentido último da sua existência.

Em último lugar, cedo ou tarde, a ética será inevitavelmente confrontada com a tarefa de avaliar e hierarquizar os valores propriamente éticos numa fundamentação que não poderá limitar-se ao resultado da discussão meramente democrática. Se tal não fosse o caso, iríamos erradamente confundir ética e política, isto é, tentaríamos constituir uma vida ética pela simples politização da ética.

Estranhamente as tensões entre o bem pessoal o bem comum não foram objecto de muitas considerações explícitas nos tratados e dicionários filosóficos, éticos ou políticos. Estão, de certeza, presentes na discussão de variadíssimas questões, mas enquanto tais, mereceriam um diálogo pluridisciplinar mais desenvolvido.

\section{Referências}

1. Ricoeur P. Soi-même comme un autre. Paris: Editions du Seuil; 1990.

2. Arendt H. A condição humana. $11^{\mathrm{a}}$ ed. rev. Tradução de Roberto Raposo e revisão técnica e apresentação de Adriano Correia. Rio de Janeiro: Forense Universitária, 2010.

3. Cabral R. Temas da ética. Braga: Publicações da Faculdade de Filosofia; 2000.

4. Papa Francisco. Fratelli tutti: Carta encíclica sobre a fraternidade e amizade social. Lisboa: Paulinas Editora; 2020.

5. Freund J. L’Essence du politique. Paris: Sirey; 1965.

6. Rawls J. A theory of Justice. Revised edition. Cambridge, MA: Harvard University Press; 1999.

7. Sen A. A Idea of Justice. Harvard: Harvard University Press; 2011.

8. Kant E. Fundamentação da Metafísica dos Costumes. Coimbra: Atlântida; 1960. 
9. Fessard G. Autorité et bien commun. Nouvelle édition revenue et augmentee par Frédéric Louzeau. Paris: Ad solem; 2015.

10. Jonas H. Le Principe Responsabilité. Une éthique pour la civilisation technologique. Paris: Les editions du Cerf ;1995.

11. Barbosa de Melo A. As tensões entre bem pessoal e bem comum (Um ponto de vista jurídico). In: Bem da pessoa e bem comum: um desafio à bioética. Coimbra: Gráfica de Coimbra; 1998.

12. Kelsen H. A teoria pura do direito. Coimbra: Almedina; 2019.

13. Hegel G. Phenomenology of Spirit. Translated by Terry Pinkard. Cambridge: Cambridge University Press; 2017.

14. Simon H. A Behavioral Model of Rational Choice. In: Models of Man, Social and Rational: Mathematical Essays on Rational Human Behavior in a Social Setting. New York: Wiley; 1957.

15. Sófocles. Antígona. Coimbra: Almedina; 2013.

16. Moeller C. A Angústia Do Homem Moderno. Petrópolis RJ: Editôra Vozes Limitada; 1968.

17. Gracia D. Fundamentos de bioética. Coimbra: Gráfica de Coimbra; 2; 2008.

18. Gracia D. (Dir). Ética de la objeción de conciencia. Colecção Guías de Ética en la práctica médica. Madrid: Fundación de las Ciencias de la Salud; 2008.

19. Ross D. The Right and the Good. Oxford: Oxford University Press; 1930.

Renaud M. O bem da pessoa, o bem comum e a objecção de consciência. Cadernos lbero-Americanos de Direito Sanitário. 2021 abr./jun.;10(2):69-88.

https://doi.org/10.17566/ciads.v10i2.793 